\title{
TINGKAT PENGETAHUAN TERHADAP POLA MAKAN DAN STATUS GIZI ANAK BALITA DI TAMAN KANAK - KANAK DENPASAR SELATAN
}

\author{
*Ni Putu Eny Sulistyadewi ${ }^{(1)}$, dan Dylla Hanggaeni Dyah Puspaningrum ${ }^{(2)}$ \\ ${ }^{1}$ Program Studi Ilmu Gizi dan ${ }^{2}$ Program Studi Perekam dan Informasi Kesehatan, Fakultas Ilmu \\ Kesehatan Sains dan Teknologi, Universitas Dhyana Pura, Badung, Bali, Indonesia. \\ *Email: enysulistyadewi88@gmail.com
}

\begin{abstract}
ABSTRAK
Pengaturan pola makan pada anak balita sangat bergantung dengan tingkat pengetahuan ibu dalam memilih, mengolah serta mengatur makanan yang dibutuhkan oleh balita. Hal ini menunjukkan bahwa pengetahuan yang dimiliki ibu tentang gizi balita akan mendasari pemberian makan pada anak, sehingga akan menentukan pola makan anak dan selanjutnya akan menentukan status gizi anak tersebut. Tujuan dari penelitian ini adalah untuk mengetahui tingkat pengetahuan terhadap pola makan dan status gizi anak balita di taman kanak - kanak Denpasar Selatan. Penelitian ini termasuk jenis penelitian observasional analitik dengan rancangan penelitian cross-sectional. Hasil penelitian dari 31 orang responden mempunyai status gizi baik dan pola makan sesuai dengan tingkat pengetahuan ibu yang kurang. Hal ini menunjukkan bahwa tidak ada hubungan tingkat pengetahuan ibu terhadap pola makan dan status gizi anak balita taman kanak - kanak Denpasar Selatan yang ditunjukkan dengan nilai $\mathrm{p}>0,05$.
\end{abstract}

Kata Kunci : Pola makan, Status Gizi, Tingkat Pengetahuan Ibu, Balita

\begin{abstract}
Dietary adjustments in children under five is very dependent on the level of knowledge of mothers in selecting, processing and arranging food needed by toddlers. This suggests that knowledge of mothers about infant nutritional would constitute feeding the child, so that will determine the child's diet and will determine the nutritional status of the child. The purpose of this study was to determine the level of knowledge of diet and nutritional status of children under five in kindergarten - childhood South of Denpasar. This research is observational analytic study with cross-sectional study design. The results of the 31 respondents have good nutritional status and diet according to the mother's level of knowledge is lacking. This shows that there is no relationship between the level of knowledge of the mother's diet and nutritional status of children under five kindergarten - childhood South of Denpasar indicated by the value of $p>0.05$.
\end{abstract}

Keyword : Diet, Nutritional Status, Knowledge Level Mother, Toddler

\section{PENDAHULUAN}

Masa balita merupakan masa perkembangan kemampuan bahasa, kreativitas, kesadaran sosial, emosional dan intelegensia yang berjalan dengan cepat dan merupakan landasan bagi perkembangan selanjutnya (Abiba, dkk., 2012). Perkembangan anak didukung oleh status gizi dan asupan gizi yang baik dan seimbang. Ketidakseimbangan gizi serta derajat kesehatan yang rendah akan sangat mempengaruhi tumbuh kembang anak (Anggraeni, 2014).

Balita merupakan kelompok yang rentan terhadap kesehatan dan gizi. Kekurangan gizi pada masa balita dapat mengakibatkan gagalnya tumbuh kembang otak anak. Gizi kurang yang terjadi pada anak-anak dapat menghambat pertumbuhan, rentan terhadap penyakit infeksi dan rendahnya tingkat kecerdasan anak. Keadaan gizi buruk secara langsung disebabkan oleh kurangnya asupan makanan dan penyakit infeksi, sedangkan secara tidak langsung disebabkan oleh ketersediaan pangan, sanitasi, pelayanan kesehatan, pola asuh, kemampuan daya beli keluarga, pendidikan dan pengetahuan (Gunawan, dkk., 2011).

Berdasarkan data Riskesdas Tahun 2013 dalam Profil Kesehatan Provinsi Bali (2014), diketahui bahwa prevalensi balita 
yang mengalami gizi kurang sebesar 10,2\%, sedangkan yang mengalami gizi lebih mencapai $5,5 \%$. Kejadian gizi lebih pada balita juga perlu mendapatkan perhatian yang khusus seperti gizi kurang, karena kasus gizi lebih mengalami peningkatan dari tahun sebelumnya. Hal ini disebabkan oleh perubahan pola hidup masyarakat yang lebih memilih makanan junk food atau fast food.

Masalah makan yang terjadi pada anak umumnya adalah pola pemberian makanan yang salah dan masalah kesulitan makanan. Pemberian makan pada anak hendaknya lebih memperhatikan kandungan gizi makanan agar kebutuhan gizi anak dapat terpenuhi dan mampu menunjang tumbuh kembang anak. Pola makan seimbang yang sesuai dengan kebutuhan disertai pemilihan bahan makanan yang tepat akan mendapatkan status gizi yang baik (Sulistyoningsih, 2012).

\section{METODE PENELITIAN}

Penelitian ini termasuk jenis penelitian observasional analitik dan desain potong lintang (cross sectional) dengan pendekatan kuantitatif. Pada penelitian ini menggunakan perhitungan rumus besar sampel simple random sampling. Penelitian ini dilaksanakan dari bulan Mei - Agustus 2016.

Data gambaran umum sampel ditabulasi kemudian disajikan dengan tabel frekuensi dan dianalisis secara deskriptif. Data pola makan sampel dengan menggunakan metode SQ-FFQ diolah dengan program nutrisurvey kemudian dibandingkan dengan kecukupan zat gizi yang dianjurkan selanjutnya dikategorikan. Data status gizi dihitung dengan menggunakan rumus $\mathrm{BB} / \mathrm{TB}$ yang kemudian hasilnya dikategorikan dan selanjutnya disajikan dengan tabel frekuensi dan dianalisis secara deskriptif.

Analisis data hasil penelitian dilakukan dengan cara deskriptif dan analitik. Data yang dianalisis secara deskriptif disajikan dalam bentuk distribusi frekuensi, tabulasi silang, nilai rata rata dan standar deviasi. Data diuji secara analitik dilakukan dengan uji Korelasi Spearman untuk data berskala ordinal.

\section{Hasil dan Pembahasan \\ Karakteristik Responden Penelitian}

Balita merupakan anak yang telah menginjak usia diatas satu tahun hingga lima tahun atau usia anak di bawah lima tahun (Muaris, 2006). Masa balita merupakan periode penting dalam proses tumbuh kembang manusia, karena menjadi penentu keberhasilan pertumbuhan dan perkembangan anak di periode selanjutnya. Masa tumbuh kembang di usia ini merupakan masa yang berlangsung cepat dan tidak akan dapat terulang yang sering disebut dengan masa keemasan (Golden Age). Distribusi karakteristik responden penelitian disajikan pada tabel 1.

Tabel 1. Distribusi Karakteristik Responden Penelitian

\begin{tabular}{clcc}
\hline No & \multicolumn{1}{c}{ Karakteristik Individu } & f & \% \\
\hline 1. & Jenis Kelamin : & & \\
& • Laki - Laki & 15 & 48,4 \\
& • Perempuan & 16 & 51,6 \\
2. & Pendidikan Ibu : & & \\
& • SD & 1 & 3,2 \\
& • SMP & 1 & 3,2 \\
& • SMA & 17 & 54,8 \\
& • Diploma & 7 & 22,6 \\
& • S1 & 5 & 16,1 \\
3. Status Gizi Berdasarkan BB/TB : & & \\
& • Kurang & 2 & 6,5 \\
& • Baik & 25 & 80,6 \\
& - Lebih & 4 & 12,9 \\
T. Tingkat Pengetahuan Ibu : & & \\
& • Baik & 2 & 6,5 \\
& • Kurang & 29 & 93,5 \\
\hline
\end{tabular}

Pada penelitian ini sebagian besar sebanyak 16 orang $(51,6 \%)$, tingkat responden berjenis kelamin perempuan yaitu pendidikan ibu responden sebagian besar 
lulusan SMA yaitu sebanyak 17 orang $(54,8 \%)$, status gizi balita berdasarkan kategori $\mathrm{BB} / \mathrm{TB}$ termasuk ke dalam kategori baik yaitu sebanyak 25 orang $(80,6 \%)$. Tingkat pengetahuan ibu responden berdasarkan hasil penelitian diketahui bahwa sebagian besar responden memiliki kategori kurang yaitu sebanyak 29 orang $(93,5 \%)$.

\section{Hubungan Tingkat Pengetahuan dengan Status Gizi Balita}

Berdasarkan penelitian yang dilakukan, diketahui bahwa sebagian besar responden penelitian yang memiliki tingkat pengetahuan ibu kurang memiliki status gizi baik yaitu sebanyak 23 orang (92\%). Distribusi hubungan tingkat pengetahuan dengan status gizi balita responden penelitian dapat dilihat pada tabel 2 dibawah ini.

Tabel 2. Hubungan Tingkat Pengetahuan dengan Status Gizi Balita

\begin{tabular}{ccccc}
\hline Tingkat & \multicolumn{3}{c}{ Status Gizi Balita } \\
Pengetahuan & $\begin{array}{c}\text { Kurang } \\
\mathrm{n}(\%)\end{array}$ & $\begin{array}{c}\text { Baik } \\
\mathrm{n}(\%)\end{array}$ & $\begin{array}{c}\text { Lebih } \\
\mathrm{n}(\%)\end{array}$ & $\mathrm{n}(\%)$ \\
\hline Baik & $0(0 \%)$ & $2(8 \%)$ & $0(0 \%)$ & $2(6,5 \%)$ \\
Kurang & $2(100 \%)$ & $23(92 \%)$ & $4(100 \%)$ & $29(93,5 \%)$ \\
Total & $2(100 \%)$ & $25(100 \%)$ & $4(100 \%)$ & $31(100 \%)$ \\
\hline
\end{tabular}

Berdasarkan Uji statistik Sperman Correlation menunjukkan bahwa tidak ada hubungan antara tingkat pengetahuan dengan status gizi balita responden penelitian dengan nilai $\mathrm{p}$ value $=0,052$ $(p>0,05)$. Tidak adanya hubungan ini terjadi karena ibu belum menerapkan pengetahuan tentang gizi balita yang dimiliki dalam kehidupan anak sehari - hari. Hal ini bisa terjadi karena berkaitan dengan keadaan ekonomi yang dimiliki oleh ibu atau waktu yang dimiliki ibu tidak sepenuhnya untuk memperhatikan anak mereka. Akibatnya anak tidak memperoleh perhatian yang optimal. Oleh sebab itu, ibu harus meluangkan waktu untuk memperhatikan anak. Selain itu, ibu harus mampu memilih bahan makanan yang mempunyai nilai gizi tinggi dengan harga yang terjangkau oleh keuangan yang dimiliki. Sehingga anak akan tercukupi kebutuhan gizinya dan perhatian yang cukup dari orang tua terutama ibu.

\section{Hubungan Tingkat Pengetahuan dengan Pola Makan}

Berdasarkan penelitian yang dilakukan, diketahui bahwa sebagian besar responden penelitian yang memiliki tingkat pengetahuan ibu kurang memiliki pola makan baik yaitu sebanyak 17 orang (94,4\%). Distribusi hubungan tingkat pengetahuan dengan pola makan responden penelitian dapat dilihat pada tabel 3 dibawah ini.

Tabel 3. Hubungan Tingkat Pengetahuan dengan Pola Makan

\begin{tabular}{|c|c|c|c|}
\hline \multirow[b]{2}{*}{ Tingkat Pengetahuan Ibu } & \multicolumn{2}{|c|}{ Pola Makan } & \multirow[b]{2}{*}{$\begin{array}{l}\text { Total } \\
\mathrm{n}(\%)\end{array}$} \\
\hline & $\begin{array}{l}\text { Baik } \\
\mathrm{n}(\%)\end{array}$ & $\begin{array}{c}\text { Tidak Baik } \\
\text { n }(\%)\end{array}$ & \\
\hline Baik & $1(5,6 \%)$ & $1(7,7 \%)$ & $2(6,5 \%)$ \\
\hline Kurang & $17(94,4 \%)$ & $12(92,3 \%)$ & $29(93,5 \%)$ \\
\hline Total & $18(100 \%)$ & $13(100 \%)$ & $31(100 \%)$ \\
\hline
\end{tabular}

Menurut Furqan (2008), pengetahuan gizi ibu merupakan tingkat pengetahuan tentang bahan makanan, yang berhubungan dengan sumber-sumber zat gizi, Pengetahuan yang kurang tentang makanan sehat akan menimbulkan anggapan bahwa makanan yang sehat adalah makanan yang mahal dan sulit didapatkan. Berdasarkan hasil penelitian terhadap 31 orang responden diketahui bahwa responden yang mempunyai pengetahuan yang kurang baik dengan pola makan balita yang tidak baik sejumlah 12 orang $(92,3 \%)$, sedangkan yang pola makan balita baik sejumlah 17 orang (94,4\%). Responden yang mempunyai pengetahuan baik dengan pola makan balita yang baik sejumlah 1 orang $(5,6 \%)$, sedangkan yang pola makan balitanya tidak baik sejumlah 1 orang $(7,7 \%)$.

Dari hasil wawancara kepada responden didapatkan tingkat pengetahuan responden tentang gizi masih kurang. Pengetahuan gizi 
ibu yang kurang akan mempengaruhi pemilihan dan pemberian makanan dalam keluarga khususnya balita sehingga dapat mempengaruhi pola makan balita. Berdasarkan hasil uji statistik Spearman Correlation menunjukkan bahwa tidak ada hubungan antara tingkat pengetahuan dengan pola makan balita $p=0,182(p>0,05)$. Hal ini berarti tidak terdapat kecenderungan antara pengetahuan gizi ibu dengan pola makan, karena salah satu faktor yang terdapat pada pola makan adalah penyediaan makanan. Faktor yang terkait dengan penyediaan makanan tidak hanya pengetahuan gizi tetapi didukung juga oleh ketersediaan dan daya beli di dalam rumah tangga. Penyediaan makanan keluarga biasanya dilakukan oleh seorang ibu, dimana banyak yang tidak memanfaatkan bahan makanan yang bergizi. Hal ini dapat disebabkan oleh kurangnya pengetahuan akan bahan makanan yang bergizi (Suhadjo, 2003).

\section{Hubungan Pola Makan dan Status Gizi Balita Responden Penelitian}

Berdasarkan penelitian yang dilakukan, diketahui bahwa sebagian besar responden penelitian yang memiliki pola makan baik memiliki status gizi baik yaitu sebanyak 17 orang (68\%). Distribusi hubungan pola makan dengan status gizi balita responden penelitian dapat dilihat pada tabel 4 dibawah ini.

Tabel 4. Hubungan Pola Makan dengan Status Gizi Balita

\begin{tabular}{ccccc}
\hline \multirow{3}{*}{ Pola Makan } & Kurang & Status Gizi Balita & Total \\
& $\mathrm{n}(\%)$ & $\mathrm{n}(\%)$ & $\mathrm{Lik}$ & $\mathrm{n}(\%)$ \\
\hline Baik & $0(0 \%)$ & $17(68 \%)$ & $1(25 \%)$ & $18(58,1 \%)$ \\
Tidak Baik & $2(100 \%)$ & $8(32 \%)$ & $3(75 \%)$ & $13(41,9 \%)$ \\
Total & $1(100 \%)$ & $25(100 \%)$ & $4(100 \%)$ & $31(100 \%)$ \\
\hline
\end{tabular}

Berdasarkan hasil penelitian terhadap 31 orang responden diketahui bahwa responden yang mempunyai pola makan baik memiliki status gizi yang baik sebanyak 17 orang (68\%), sedangkan pola makan tidak baik memiliki status gizi yang baik pula ada sebanyak 8 orang (32\%). Namun berdasarkan hasil uji statistik Spearman Correlation menunjukkan bahwa tidak ada hubungan antara pola makan dan status gizi $\mathrm{p}=0,215 \quad(\mathrm{p}>0,05)$. Hal ini serupa dengan hasil penelitian Diana (2004) yang menyatakan bahwa tidak ada hubungan antara pola asuh pemberian makanan dengan status gizi balita. Menurut Soetjiningsih (2010), status gizi ditentukan oleh kecukupan makanan dan kemampuan tubuh yang mengandung zat gizi untuk kesehatan. Apabila kecukupan konsumsi makanan kurang, maka akan mempermudah timbulnya penyakit yang pada akhirnya akan mempengaruhi pertumbuhan dan mengakibatkan status gizi menurun.

Pola makan pada anak usia sekolah sangat berperan penting dalam proses pertumbuhannya. Hal ini karena dalam makanan banyak mengandung zat - zat gizi. Zat gizi tersebut memiliki keterkaitan yang sangat erat hubungannya dengan kesehatan dan kecerdasan serta tumbuh kembang anak.
Apabila pola makan tidak tercapai dengan baik pada anak, maka masa pertumbuhan dan perkembangannya akan mengalami gangguan. Hal ini akan dapat menyebabkan tubuh kurus, pendek, bahkan dapat menyebabkan terjadinya gizi buruh pada anak balita (Proverawati \& Asfuah, 2010). Responden yang memiliki pola makan tidak baik akan tetapi memiliki status gizi baik dikarenakan adanya faktor penyebab yang lainnya, yaitu kondisi kesehatan anak. Selain itu, bisa juga disebabkan oleh aktivitas anak tidak terlalu tinggi sehingga dengan pola makan yang tidak baik dalam satu bulan terakhir anak akan tetap memiliki status gizi baik. Anak yang memiliki pola makan baik ada yang memiliki status gizi lebih. Hal ini disebabkan karena faktor konsumsi makanan yang mengandung lemak, gula dan karbohidrat yang tinggi serta ditambah dengan aktivitas anak yang kurang, sehingga menyebabkan kalori yang masuk akan lebih banyak daripada yang akan dikeluarkan sehingga anak menjadi gemuk.

\section{KESIMPULAN}

Adapun simpulan yang dapat ditarik dari penelitian ini yaitu : tidak ada hubungan antara tingkat pengetahuan terhadap pola makan dan status gizi anak balita di Taman 
Kanak - Kanak Denpasar Selatan yang ditunjukkan dengan nilai $p>0,05$. Tingkat pengetahuan tidak berpengaruh terhadap pola makan dan status gizi anak balita di Taman Kanak - Kanak Denpasar Selatan.

\section{DAFTAR PUSTAKA}

Abiba, A., Grace, A.N.K., dan Kubreziga, K.C. 2012. Effects of Dietary Patterns on The Nutritional Status of Upper Primary School Children In Tamale Metropolis. Pakistan Journal of Nutrition, 11(7), 591-609.

Anggreani, M.N. 2014. Perkembangan Motorik Halus Pada Anak Usia 3-5 Tahun Berdasarkan Status Gizi Di Desa Sindurjan Kecamatan Purworejo Kabupaten Purworejo. Jurnal Gizi dan Kesehatan, Vol 6 No 2.

Diana, F.M, 2004. Hubungan Pola Asuh Dengan Status Gizi Anak Balita Di Kacamatan Kurasi Kelurahan Pasar Ambacang Kota Padang Tahun 2004, Padang, Universitas Andalas.
Dinas Kesehatan Provinsi Bali. 2015. Bali. Profil Kesehatan Provinsi Bali 2014.

Furqan, M. 2008. Pentingnya Pengetahuan Gizi Bagi Ibu. (http://www.peduligizi.com diakses tanggal 10 November 2011)

Gunawan G, Fadlyana E, Rusmil K. 2011. Hubungan Status Gizi dan Perkembangan Anak Usia 1-2 Tahun. Sari Pediatri. Agustus; 13(2).

Muaris, H. 2006. Sarapan Sehat Untuk Anak Balita. Jakarta : PT. Gramedia Pustaka Utama.

Proverawati,A. 2010. Ilmu Gizi untuk Keperawatan dan Kesehatan. Yogyakarta : Nuha Medika.

Soetjiningsih, 2010.Tumbuh Kembang Anak, Jakarta: EGC

Suhardjo, 2003. Perencanaan Pangan dan Gizi. Jakarta : BumiAksara.

Sulistyoningsih, H. 2012. Gizi Untuk Kesehatan Ibu dan Anak. Yogyakarta : Graha Ilmu. 